\title{
Religious People only Live Longer in Religious Cultural Contexts: \\ A Gravestone Analysis
}

\author{
Tobias Ebert \\ University of Mannheim
}

Jildou R. Talman

Leiden University

\author{
Jochen E. Gebauer \\ University of Mannheim \& University of \\ Copenhagen \\ P. Jason Rentfrow \\ University of Cambridge
}

Tobias Ebert, Mannheim Centre for European Social Research, University of Mannheim, Germany;

Jochen Gebauer Mannheim Centre for European Social Research, University of Mannheim, Germany and Department of Psychology, University of Copenhagen, Denmark;

Jildou R. Talman, Department of Psychology, Leiden University, The Netherlands;

P. Jason Rentfrow, Department of Psychology, University of Cambridge, UK

Corresponding author: Tobias Ebert, Mannheim Centre for European Social Research, University of Mannheim, A5, 6, D-68159 Mannheim, Germany (email: tobias.ebert@mzes.unimannheim.de). 


\begin{abstract}
Religious people live longer than non-religious people according to a staple of social science research. Yet, are those longevity benefits an inherent feature of religiosity? To find out, we coded gravestone inscriptions and imagery in order to assess the religiosity and longevity of 6,400 deceased people from religious and non-religious U.S. counties. We show that in religious cultural contexts, religious people lived 2.2 years longer than did non-religious people. In non-religious cultural contexts, however, religiosity conferred no such longevity benefits. Evidently, a longer life is not an inherent feature of religiosity. Instead, religious people only live longer in religious cultural contexts where religiosity is valued. Our study answers a fundamental question on the nature of religiosity and showcases the scientific potential of gravestone analyses.
\end{abstract}

Keywords: Religiosity, Gravestones, Longevity, Cross-Cultural Differences 
There is widespread consensus that religious people live longer than non-religious people (Chida, Steptoe, \& Powell, 2009; McCullough, Hoyt, Larson, Koenig, \& Thoresen, 2000; Shor \& Roelfs, 2013). The mainstream view in the social sciences is that those longevity benefits are inherent to religiosity (e.g., via religious practices that promote health). Consequently, this mainstream view is a cultural-universal view stipulating that all religious people enjoy the same longevity benefits, irrespective of their cultural context. Alternatively, religiosity's longevity benefits may not be inherent to religiosity, but driven by a contextual feature shared by most published research (Sedikides \& Gebauer, 2010). In religious cultural contexts, religious people receive much social valuation for being religious (Gebauer, Sedikides, \& Neberich, 2012; Gebauer et al., 2017). Thus, the longevity benefits of religiosity might result from that greater social valuation, rather than from religiosity itself. If this alternative view was correct, the longevity benefits of religiosity should be culture-specific, i.e., strong in religious cultural contexts and absent in non-religious contexts.

There is a huge amount of evidence for religiosity's longevity benefits. However, little is known about those benefits' cross-cultural variability. The only two studies that investigated cross-cultural differences arrived at different conclusions.

First, Stavrova (2015) used large-scale representative survey data and found strong cultural variation in the religiosity-longevity link across 59 countries and 9 U.S. census regions. However, past research found that self-reported religiosity data can be heavily biased. Hadaway, Marler, and Chaves (1993), for example, compared self-reported church attendance with actual headcounts in the U.S. The researchers estimated that U.S. Americans overestimate their number of church visits by $100 \%$. Issues with data confidentiality and anonymity pose an additional limitation to survey data. Specifically, researchers typically have no access to fine-grained information about the participants' places of residence (i.e., counties or census regions). Religiosity is a highly localized phenomenon (Warf \& Winsberg, 2008), rendering such fine-grained geographic information particularly relevant (cf. 
Oberwittler \& Wikström, 2009). Second, Wallace, Anthony, End, and Way (2019) examined religious content in 1,042 obituaries across 42 U.S. cities. They found no evidence for an interaction effect between individual-level and city-level religiosity on longevity. However, this study was restricted to a selective subpopulation (urban people from select cities, who had obituaries in newspapers). Thus, it is unknown whether the findings generalize to the population at large.

Taken together, unequivocal evidence for cross-cultural variation in the religiositylongevity link would have far-reaching scientific and societal implications. For example, such evidence would call for a revision of the idea that religiosity's longevity benefits are inherent and suggest that turning to religiosity is not beneficial everywhere. Unfortunately, the existent evidence is not unequivocal as it (a) used self-reported assessments of religiosity with restricted validity, and/or (b) (if at all) compared large-scale areas that might be too broad to represent truly relevant contexts, and/or (c) relied on samples that excluded large societal strata.

The present investigation uses a unique and entirely novel empirical approach to examine whether religiosity's longevity benefits are restricted to religious cultural contexts. Specifically, we use cemeteries as our data source and measure people's longevity and religiosity by the inscriptions and imagery on their gravestones.

Geographers, historians, and cultural scientists (Hijiya, 1983; Saller \& Shaw, 1984; Zelinsky, 2007) have long recognized that gravestones preserve important information about the people buried beneath them. Gravestones often carry religious imagery, which makes them a particularly useful indicator of deceased people's religiosity. For one thing, the available space on a gravestone is restricted, and, hence, only the most important or memorable characteristics of a person are usually included. For another thing, "[a decedent, spouse, or close family member] is more likely to devote greater time and effort in deciding what, if anything, to put on a permanent memorial - usually a decidedly costly commodity 
and once-in-a-lifetime transaction" (Zelinsky, 2007, p. 447). Consequently, gravestone imagery might provide particularly valid information about deceased people. That way, studying gravestones could be less prone to the perennial problem of response bias in survey research. Figure 1 provides illustrative examples from our data contrasting prototypical religious from non-religious gravestones.

Beyond the "set-in-stone" aspect of our methodology, gravestone analyses provide two additional advantages. First, cemeteries are one of the few institutions in today's world that bring together otherwise heavily segregated groups. For example, in the U.S., black and white people share the same cemeteries since 1969 (Rogers, 2005). Consequently, studying gravestones comes close to a probabilistic sampling approach. Thus, gravestone analyses are relatively immune to otherwise frequent sampling biases, such as under-sampling rural, working-class, and ethnically diverse subpopulations (Gurven, 2018). Second, cemeteries are everywhere and we know their exact locations. Hence, sampling from cemeteries allows examining cultural variation at those fine-grained geographical levels that are particularly relevant (Kashima et al., 2004; Warf \& Winsberg, 2008), but often unavailable to researchers. 


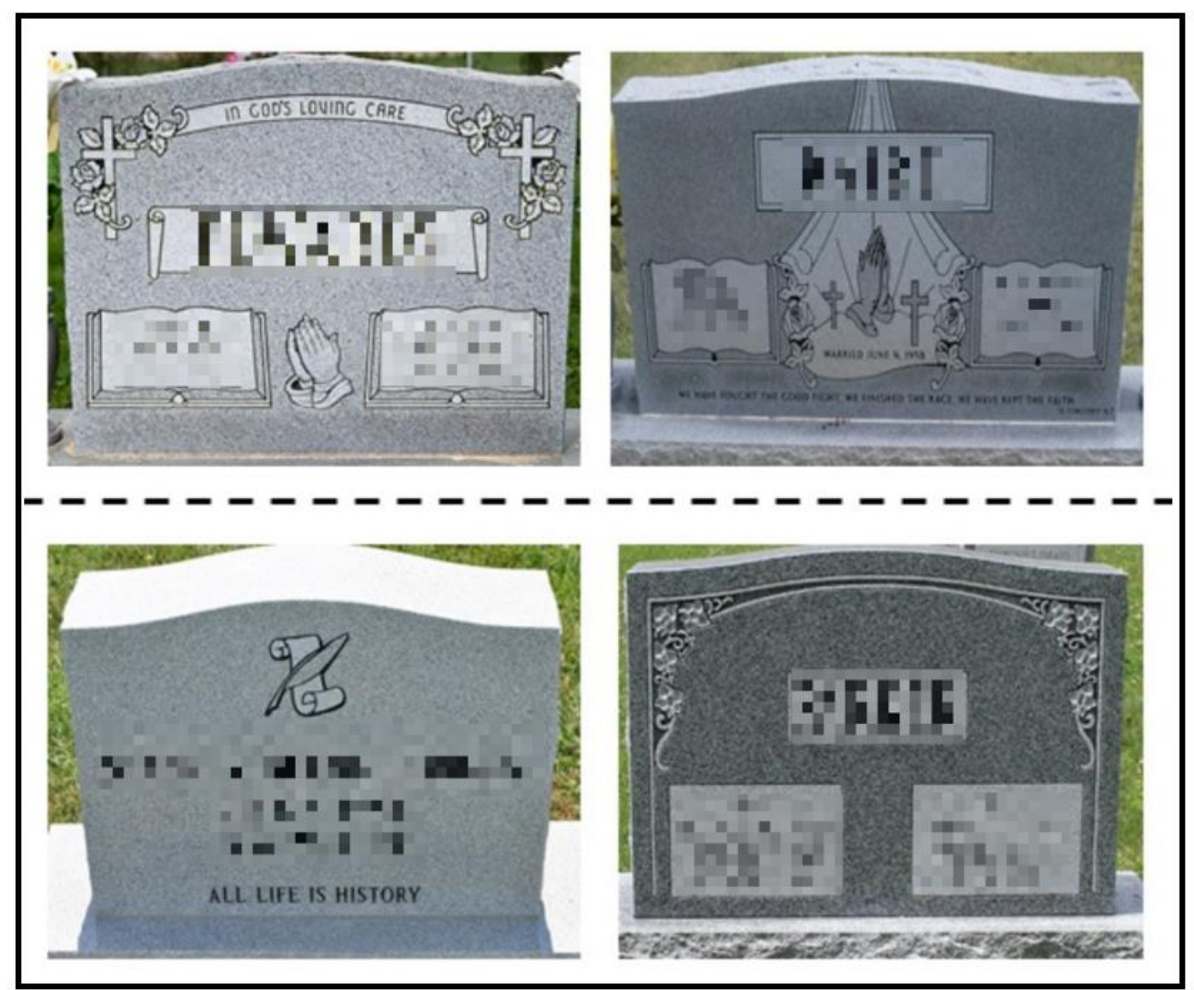

Figure 1. Prototypical religious gravestones (top row) and gravestones with nonreligious imagery (bottom left) or no imagery (bottom right).

\section{Data and Methods}

\section{Sampling and Coding Approach}

We analyzed the association between religiosity and longevity based on large-scale gravestone data. Our study focuses on Christians (vs. non-believers) in the U.S. - the denomination and country that is typically studied in religiosity research. We set up an $a$ priori sampling strategy (see Sampling and Coding Description in Online Supplement), to select which areas and graves to include in our analyses. In short, we collected data from a sample of 6,400 deceased people from 64 U.S. counties. To do so, we relied on publicly available information from the U.S. religion census and the internet archive findagrave.com.

First, we used the U.S. religion census to calculate the share of Christians (i.e., cumulated share of Catholics and Protestants) within counties. Based on this county religiosity measure, we stratified the sampling of the 64 counties so that $50 \%$ represent religious cultural contexts (i.e., high share of Christians) and 50\% non-religious cultural 
contexts (i.e., low share of Christians). In each cultural context (i.e., religious and nonreligious) $50 \%$ of the counties were urban (i.e., inside metropolitan areas) and 50\% were rural (i.e., outside metropolitan areas). Figure 2 depicts the geographical distribution of the sampled counties.

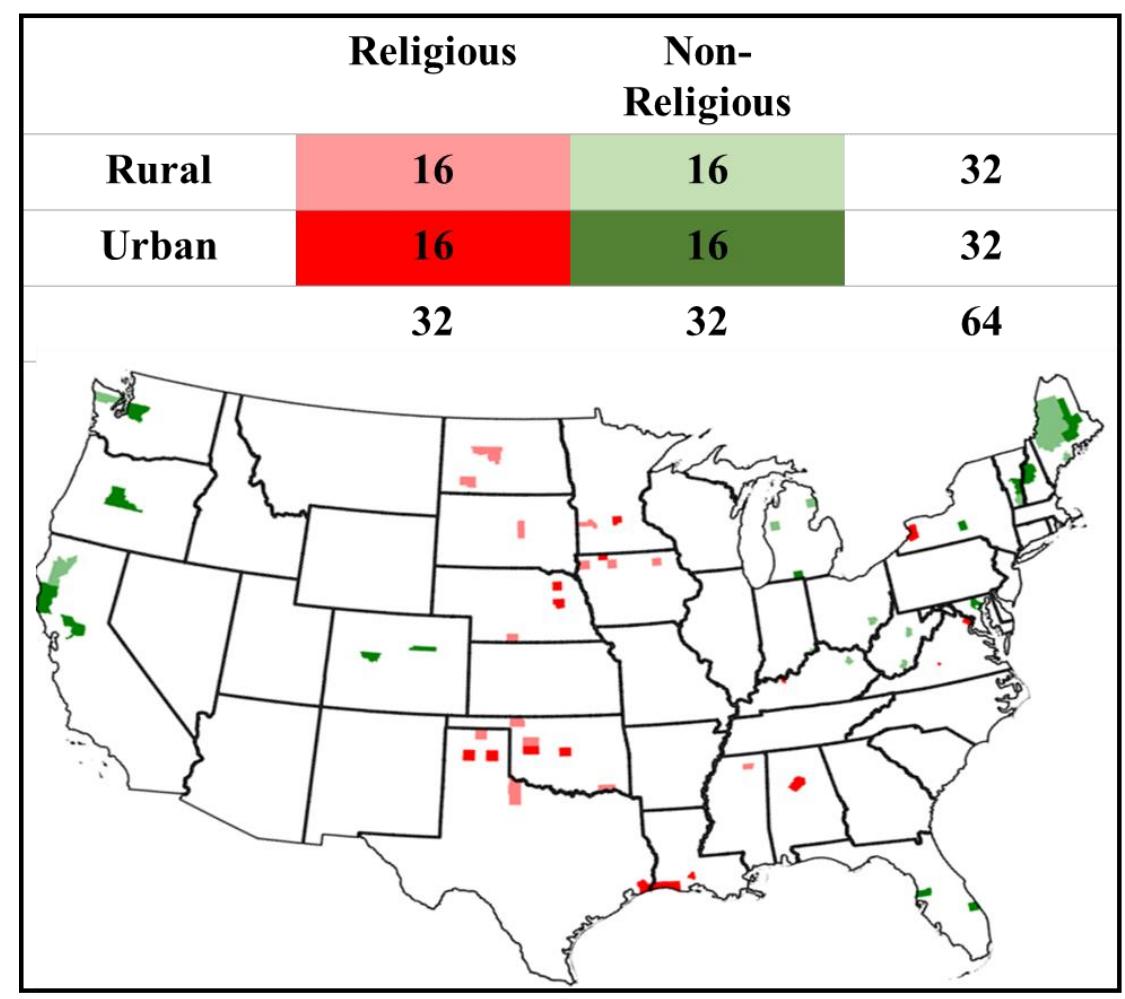

Figure 2. Geographical distribution of sampled counties.

Second, we used the gravestone photographs provided on findagrave.com to assess the religiosity and longevity of 100 deceased people in each sampled cemetery (50\% male and $50 \%$ female, all passed away since January $1^{\text {st }} 2000$ ). On average, findagrave.com provided a gravestone photograph for $81 \%$ of all deceased people across all cemeteries. To measure religiosity we coded the imagery displayed on each gravestone following Zelinsky's gravestone classification scheme (Zelinsky, 2007). Tables S1-S2 provide the coding manual, coding examples, and tests of coding reliability. The descriptive statistics (Table S3) showcase the gravestone approach's merits. First, gravestones indeed frequently carry religious imagery (44\% of all gravestones). Second, life expectancy in our sample (78.79 years) closely matched official statistics (78.54 years in 2017). Third, our sample of counties 
also covered remote populations that conventional studies often neglect, such as counties with less than one inhabitant per square mile.

\section{Gravestone Religiosity Index}

We distinguish between five elements of religious imagery that occurred frequently (Figure 3): the cross (appearing on 29\% of all gravestones), book symbols representing the bible or the book of life (10\%), hands folded in prayer (7\%), passages of scripture $(6 \%)$, and angels (2\%). Consistent with the expectation that religiosity is reflected on deceased people's gravestones, we observed significantly more gravestones with religious imagery in religious counties $(M=.48)$ than in non-religious counties $(M=.37), t(6,398)=-9.42, p<.001$. Three elements discriminated particularly well between religious and non-religious counties: books, $t(6,398)=-9.12, p<.001$, praying hands, $t(6,398)=-6.77, p<.001$, and angels, $t(6,398)=-$ $3.48, p<.001$. The presence of Book-Praying-Angel imagery performed equally well in urban counties $\left(M_{\text {religious }}=0.21 / M_{\text {non-religious }}=0.10 ; t(3,198)=-8.03, p<.001\right)$ and rural counties $\left(M_{\text {religious }}=0.23 / M_{\text {non-religious }}=0.12 ; t(3,198)=-8.22, p<.001\right)$. By contrast, the presence of Cross-Verbal imagery only discriminated in urban settings $\left(M_{\text {religious }}=0.32 / M_{\text {non-religious }}=\right.$ $0.41 ; t(3,198)=-5.13, p<.001)$, but not in rural settings $\left(M_{\text {religious }}=0.29 / M_{\text {non-religious }}=0.30 ;\right.$ $\mathrm{t}(3,198)=-0.931, p=.35)$. 


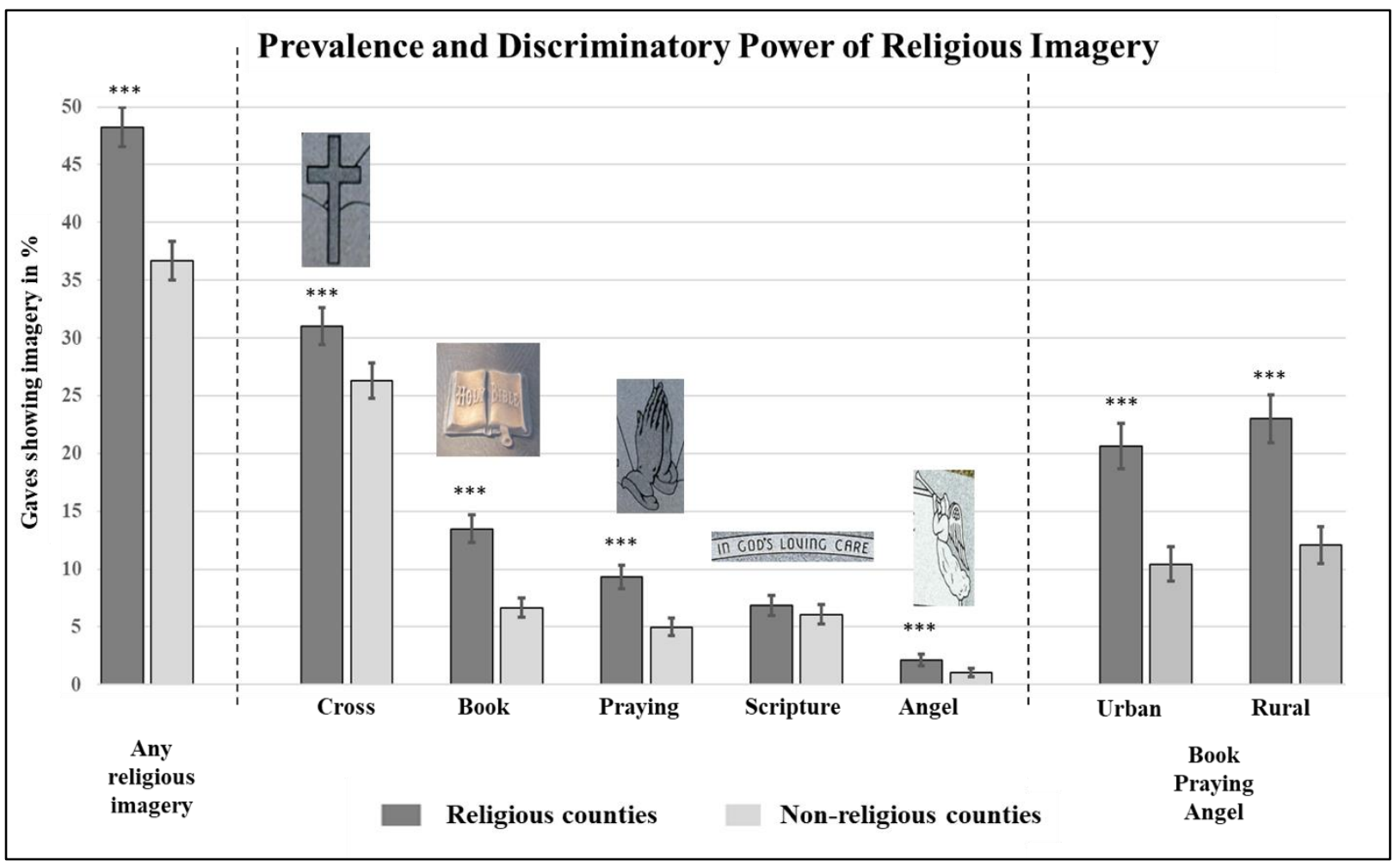

Figure 3. Prevalence of religious imagery across religious and non-religious counties.

To further ensure that Book-Praying-Angel imagery indeed reflects deceased people's religiosity (i.e., to avoid the ecological fallacy; Robinson, 1950) we cross-validated them with additional individual-level information (see Gravestone Religiosity Measure in Online Supplement). Specifically, we researched short biographies of deceased people that are occasionally provided on findagrave.com (448 out of 6,400 observations). We then used natural language processing based on the well-established LIWC dictionary (Pennebaker, Boyd, Jordan, \& Blackburn, 2015) to analyze the relative frequency of religious words within these biographies. In line with our aggregate-level findings, deceased people with BookPraying-Angel imagery on their gravestone featured a $48 \%$ higher share of religious words within their biographies than people without such imagery $\left(M_{\mathrm{bpa}}=.044 / M_{\text {non-bpa }}=.029\right.$; $t(446)=-4.56, p<.001)$. By contrast, for the poorly discriminating imagery elements (i.e., cross and verbal scriptures) only a non-significant difference of $15 \%$ in the share of religious words emerged $\left(M_{\mathrm{cv}}=.035 / M_{\text {non-cv }}=.030 ; t(446)=-1.82, p=.07\right)$. 
Taken together, evidence from the aggregate level and the individual level converges, suggesting that a deceased person's religiosity can be validly assessed by the presence of books, praying hands, and angels on that person's gravestone. We, thus, devised a gravestone religiosity index (see Gravestone Religiosity Measure in Online Supplement) that sums up the three well discriminating elements and relativizes that sum by the total number of imagery elements on the gravestone (results were conceptually identical with other operationalizations; see robustness checks later).

\section{Analysis Method}

Previous research found that religiosity is not related to unusually early mortality (e.g., due to traffic accidents). For instance, McCullough, Friedman, Enders, and Martin (2009) found that religious and non-religious people start to differ in their mortality from age 70-75 onwards, with the greatest difference at age 90-100. Consequently, our main-text analyses include people who were between 70 to 99 years old when they died. In our robustness checks, however, we used other age cut-offs and found our results robust to those different cut-offs.

Our main-text analyses relied on data from 4,946 deceased people. To account for the nested data structure (deceased people nested in counties), we used linear mixed-effects modeling (Snijders \& Bosker, 1999). Longevity served as the criterion in all mixed-effects models. In the basic model, gravestone religiosity and the two stratification criteria (gender and urbanity) served as level-1 predictors, census information on the share of religious adherents per county (county religiosity) served as a level-2 predictor, and the cross-level interaction between gravestone religiosity $\times$ county religiosity (both $\mathrm{z}$-standardized) was 
modeled as an additional predictor. We specified random intercepts and random slopes of gravestone religiosity.

\section{Results}

Our basic model revealed no main effect of gravestone religiosity on longevity, $B=-$ $0.001,95 \% \mathrm{CI}[-0.22,0.21], p=.99$, but a significant cross-level interaction between gravestone religiosity $\times$ county religiosity, $B=0.30,95 \% \mathrm{CI}[0.10,0.50], p=.004$. In the most religious county (Figure 4$)$, the most religious people $(M=86.82, S D=0.75)$ lived 2.24 years longer than the least religious people $(M=84.58, S D=0.32), B=0.53,95 \% \mathrm{CI}[0.18$, 0.89], $p=.003$. This longevity benefit, however, vanished with decreasing county-level religiosity. In the least religious counties, the most religious people $(M=82.91, S D=0.85)$ tended to live 1.72 years shorter than non-religious people $(M=84.63, S D=0.26), B=-0.41$, $95 \%$ CI $[-0.81,-0.01], p=.05$. Taken together, there is great cross-cultural variation in the link between religiosity and longevity. In religious cultural contexts, the most religious people lived an average of 3.91 years longer than in non-religious cultural contexts. This is a longevity difference of considerable magnitude that exceeds gender differences (2.44 years) in our models and is comparable to the impact of severe obesity on longevity (Fontaine, Redden, Wang, Westfall, \& Allison, 2003). 


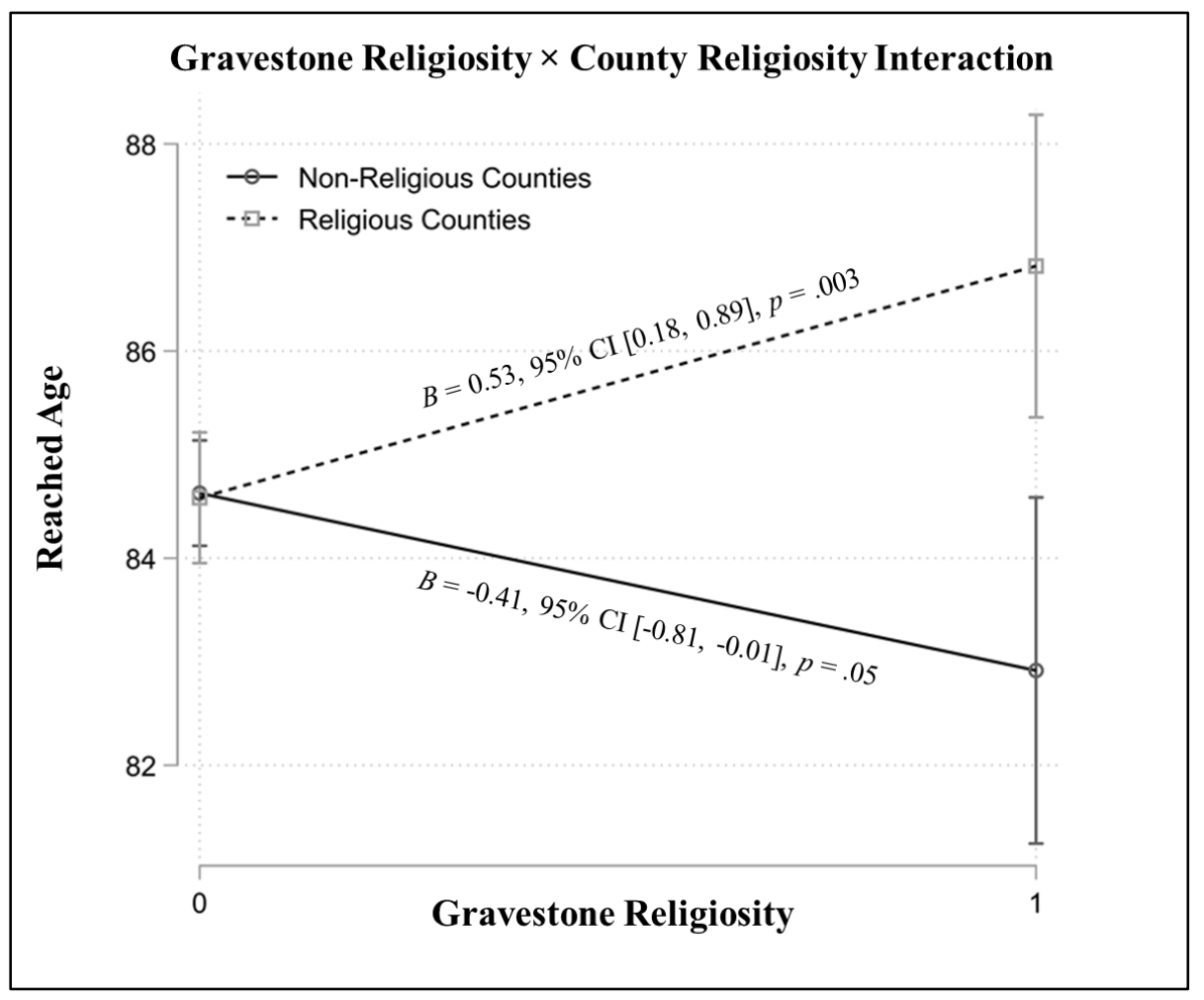

Figure 4. Interaction between gravestone religiosity and county-level religiosity on longevity.

We conducted 14 robustness checks (see Robustness Checks in Online Supplement) to scrutinize the robustness of our basic finding (M1). First, we tested against individual-level confounds (R1: total number of imagery elements, presence of non-religious imagery, marital status, number of people in grave, type of gravestone, floral or wheat ornamentation) and county-level confounds (R2: racial composition, population density, various health determinants). Second, we controlled for influences of superordinate cultural levels by including state-fixed effects (R3). Third, we added three-way interaction terms consisting of Gravestone Religiosity $\times$ County Religiosity $\times$ Stratification criteria to test for moderating effects of the two stratification criteria gender (R4) and urbanity (R5). Fourth, we lowered (R6: 63.5-99 years) and raised (R7: 75-99 years) the age-cut offs and also included people who reached an age of 100+ (R8). Fifth, we operationalized gravestone religiosity not as the share of Book-Praying-Angel imagery, but in form of a dummy (R9), a sum (R10), and a ratio (R11). Sixth, we included only those 1,065 people for which occasionally available 
information ensured that their county of death and burial were identical (R12). Sixth, we controlled for cohort and period effects by accounting for year of birth (R13) and year of death (R14). Finally, we corrected the $p$-values of our models for multiple testing (Table S5). For all these robustness checks, the results were conceptually identical with the main-text results. Taken together, our results strongly suggest that the longevity benefits of religiosity are not cultural universal. Instead, those longevity benefits were restricted to religious cultural contexts and vanished altogether in non-religious cultural contexts.

\section{Discussion}

A large body of social scientific research suggests that religious people live longer lives (Chida et al., 2009; McCullough et al., 2000; Shor \& Roelfs, 2013). However, it has been unclear whether these longevity benefits are inherent to religiosity (and thus culturally universal) or dependent on the religiosity of the adherent's cultural context. We found that the longevity benefits of religiosity are not evident everywhere (i.e., are not cultural universal), but are limited to religious cultural contexts. Our study is the first psychological study to ever rest on gravestones and it strongly suggests that gravestone imagery can provide valid information about deceased people's religiosity. By studying gravestone imagery, we were able to examine a valid religiosity marker across representative samples and fine-grained local cultures. We, thus, understand our study as a conservative, comprehensive, and much-needed extension of the influential research on the religiosity-longevity relationship.

Although our gravestone approach has key advantages over previous approaches, our approach also has its limitations. First, gravestone analyses are necessarily cross-sectional (people only die once). While we controlled for a wide variety of potential confounds in our 14 robustness checks, we cannot fully rule out reversed causality (i.e., older people in some areas being particularly likely to put religious imagery on their gravestones). However, this interpretation would be at odds with findings showing that religiosity is fairly stable across the lifespan, especially in the later stages of life (McCullough et al., 2009). Second, 
gravestone data circumvent several biases inherent in survey data, but gravestone data likely have their unique biases. For example, gravestone imagery may sometimes be chosen by the deceased people themselves (akin to self-reports) and sometimes by people close to the deceased (akin to peer-reports). Likewise, little is known about how the financial cost of imagery, the availability of craftsmanship, and local imagery norms affect gravestone data. Importantly, the biases inherent in gravestone data are probably very different from the biases inherent in survey data. Thus, the validity of any given hypothesis is particularly well supported if both types of data reveal evidence for that hypothesis. The present research in tandem with previous survey research (Gebauer et al., 2012, 2017) renders the cultural specificity of religiosity's benefits such a well-supported hypothesis.

Limitations notwithstanding, our findings have at least four significant implications. First, our findings suggest that the longevity benefits of religiosity only emerge in religious cultural contexts. Our study, thus, challenges a longstanding staple of research and it does so using a rigorous methodological approach (i.e., a set-in-stone measure of religiosity, representative sampling, and fine-grained local cultures). The findings also shed light on the mechanisms driving religious longevity benefits. Evidently, religiosity's longevity benefits are not due to some inherent feature of religiosity. Instead, they may be due to the more general phenomenon that people enjoy health benefits if they receive social valuation from their ambient cultural context (Gebauer et al., 2012, 2017). Second, from a broader data science perspective, we provide a large-scale, empirically driven validity check of gravestone information. Gravestones provide insights on important life domains beyond religiosity (e.g., hobbies/interests, political views or patriotism, see Table S1). Our study, thus, highlights that gravestones are a widely overlooked, but valuable scientific data source. Third, from a societal perspective, becoming religious has been thought of as a powerful health “intervention” (Lucchetti, Lucchetti, \& Koenig, 2011). However, our findings suggest that such religiosity-based health interventions might be effective only in religious cultural 
contexts. Finally, our study holds important implications for a Western world that is becoming increasingly secularized (Joshanloo \& Gebauer, 2019). Religiosity does not delay death everywhere and rising secularization will probably not curb collective life expectancy in the future. 


\section{References}

Association of Statisticians of American Religious Bodies (2010). Religious congregations and membership study, 2000 and 2010. Retrieved from http://www.usreligioncensus.org/.

Bates, D., Kliegl, R., Vasishth, S., \& Baayen, H. (2015). Parsimonious mixed models. arXiv preprint arXiv:1506.04967.

Centers for Disease Control and Prevention (2019). Social Determinants of Health: Know What Affects Health. Retrieved from: https://www.cdc.gov/socialdeterminants/index.htm.

Chida, Y., Steptoe, A., \& Powell, L. H. (2009). Religiosity/spirituality and mortality: A systematic quantitative review. Psychotherapy and Psychosomatics, 78, 81-90.

County Health Rankings \& Roadmaps (2019). County Health Rankings \& Roadmaps Building a Culture of Health, County by County. Retrieved from: http://www.countyhealthrankings.org

Find A Grave (2019). World's largest gravesite collection. Over 170 million memorials created by the community since 1995. Retrieved from https://www.findagrave.com/.

Fontaine, K. R., Redden, D. T., Wang, C., Westfall, A. O., \& Allison, D. B. (2003). Years of life lost due to obesity. JAMA - Journal of the American Medical Association, 289, 187-193.

Gebauer, J. E., Sedikides, C., \& Neberich, W. (2012). Religiosity, social self-esteem, and psychological adjustment: On the cross-cultural specificity of the psychological benefits of religiosity. Psychological Science, 23, 158-160.

Gebauer, J. E., Sedikides, C., Schönbrodt, F., Bleidorn, W., Rentfrow, J., Potter, J., \& Gosling, S. (2017). The religiosity as social value hypothesis: A multi-method replication and extension across 65 countries and three levels of spatial aggregation. Journal of Personality and Social Psychology, 113, e18-e39. 
Gurven, M. D. (2018). Broadening horizons: Sample diversity and socioecological theory are essential to the future of psychological science. Proceedings of the National Academy of Sciences, 115, 11420-11427.

Gwet, K. (2014). Handbook of Inter-Rater Reliability: The Definitive Guide to Measuring the Extent of Agreement Among Raters. Gaithersburg, MD: Advcanced Analytics, LLC.

Hadaway, C. K., Marler, P. L., \& Chaves, M. (1993). What the polls don’t show: A closer look at US church attendance. American Sociological Review, 58, 741-752.

Hijiya, J. A. (1983). American gravestones and attitudes toward death: A brief history. Proceedings of the American Philosophical Society, 127, 339-363.

Joshanloo, M., \& Gebauer, J. E. (2019). Religiosity’s nomological network and temporal change: Introducing an extensive country-level religiosity index based on Gallup World Poll data. European Psychologist. Advance online publication. doi: $10.1027 / 1016-9040 / \mathrm{a} 000382$

Kashima, Y., Kokubo, T., Kashima, E. S., Boxall, D., Yamaguchi, S., \& Macrae, K. (2004). Culture and self: Are there within-culture differences in self between metropolitan areas and regional cities? Personality and Social Psychology Bulletin, 30, 816-823.

Lucchetti, G., Lucchetti, A. L., \& Koenig, H. G. (2011). Impact of spirituality/religiosity on mortality: comparison with other health interventions. Explore, 7, 234-238.

Maas, C. J. M., \& Hox, J. J. (2005). Sufficient sample sizes for multilevel modeling. Methodology, 1, 85-91.

McCullough, M. E., Friedman, H. S., Enders, C. K., \& Martin, L. R. (2009). Does devoutness delay death? Psychological investment in religion and its association with longevity in the Terman sample. Journal of Personality and Social Psychology, 97, 866-882.

McCullough, M. E., Hoyt, W. T., Larson, D. B., Koenig, H. G., \& Thoresen, C. (2000). Religious involvement and mortality: A meta-analytic review. Health Psychology, $19,211-222$. 
National Center for Health Statistics (2019). NCHS Urban-Rural Classification Scheme for Counties. Retrieved from https://www.cdc.gov/nchs/data_access/urban_rural.htm.

Oberwittler, D., \& Wikström, P. O. H. (2009). Why small is better: Advancing the study of the role of behavioral contexts in crime causation. In D. Weisburd, W. Bernasco, \& G. J. N. Bruinsma (Eds.), Putting crime in its place (pp. 35-59). New York: Springer.

Pennebaker, J.W., Boyd, R. L., Jordan, K. \& Blackburn, K. (2015). The development and psychometric properties of LIWC2015. Austin, TX: University of Texas at Austin.

Robinson, W. S. (1950). Ecological correlations and the behavior of individuals. American Sociological Review, 15, 351-357.

Rogers, K. (2005). Integrating the city of the dead: The integration of cemeteries and the evolution of property law, 1900-1969. Alabama Law Review, 56, 1153-1187.

Saller, R. P., \& Shaw, B. D. (1984). Tombstones and Roman family relations in the Principate: Civilians, soldiers and slaves. The Journal of Roman Studies, 74, 124156.

Sedikides, C., \& Gebauer, J. E. (2010). Religiosity as self-enhancement: A meta-analysis of the relation between socially desirable responding and religiosity. Personality and Social Psychology Review, 14, 17-36.

Shor, E., \& Roelfs, D. J. (2013). The longevity effects of religious and nonreligious participation: A meta-analysis and meta-regression. Journal for the Scientific Study of Religion, 52, 120-145.

Snijders, T. A. B., \& Bosker, R. J. (1999). Multilevel analysis: An introduction to basic and advanced multilevel modeling. Thousand Oaks, CA: Sage

Stavrova, O. (2015). Religion, self-rated health, and mortality: Whether religiosity delays death depends on the cultural context. Social Psychological and Personality Science, $6,911-922$. 
United States Census Bureau (2019), American Community Survey, Retrieved from https://www.census.gov/programs-surveys/acs/.

Wallace, L. E., Anthony, R., End, C. M., \& Way, B. M. (2019). Does religion stave off the grave? Religious affiliation in one's obituary and longevity. Social Psychological and Personality Science, 10, 662-670.

Warf, B., \& Winsberg, M. (2008). The geography of religious diversity in the United States. The Professional Geographer, 60, 413-424.

Welbers, K., Van Atteveldt, W., \& Benoit, K. (2017). Text analysis in R. Communication Methods and Measures, 11, 245-265.

Yekutieli, D. \& Benjamini, Y. (2001). The control of the false discovery rate in multiple testing under dependency. Annals of Statistics, 29, 1165-1118.

Zelinsky, W. (2007). The Gravestone Index: Tracking personal religiosity across nations, regions, and periods. Geographical Review, 97, 441-466. 


\section{Supplementary Materials for}

Religious People only Live Longer in Religious Cultural Contexts:

A Gravestone Analysis 


\section{Sampling and Coding Description}

\section{Sampling Approach}

To select appropriate areas and gravestones for this study, we used a two-step sampling approach. Step 1 aimed at sampling a set of U.S. areas representing (a) religious and nonreligious cultural contexts from (b) a diverse background of rural and urban living environments. Geographical differences in religiosity follow rather fine-grained distributional patterns (Warf \& Winsberg, 2008). We, therefore, chose counties as our level of analysis as they are the smallest spatial level for which comprehensive religiosity information is available. To distinguish between religious and non-religious counties, we calculated the proportion of Christians in each of the 3,143 U.S counties (i.e., number of people with Catholic, Evangelical, or Mainline Protestant $^{1}$ denomination relative to the county's population according to census data, averaged across years 2000 and 2010; Association of Statisticians of American Religious Bodies, 2010). To distinguish between urban and rural counties, we identified counties that are located outside metropolitan areas (i.e., rural, $N=1,335$ ) or inside metropolitan areas (i.e., urban, $N=1,808$ ) (based on the NCHS Urban-Rural Classification Scheme for Counties; National Center for Health Statistics, 2019). To sample religious and non-religious counties from rural living environments, we used the list of 1,335 counties outside metropolitan areas and identified those 133 counties belonging to the $10 \%$ most religious and those 133 counties belonging to the $10 \%$ least religious counties. From each of these two subsets (top and bottom 10\%), we randomly chose 16 counties. To sample religious and non-religious counties from urban living environments, we used the list of 1,808 counties inside metropolitan areas and identified those

\footnotetext{
${ }^{1}$ There are different ways to group the Protestant population. We differentiate between Evangelical and Mainline Protestants. That differentiation is commonly used (e.g., by the U.S. religion census) and largely exhaustive of the Protestant population.
} 
360 counties belonging to the $20 \%$ most religious counties and those 360 counties belonging to the $20 \%$ least religious counties. In the urban setting, expanding to the top and bottom $20 \%$ (instead of 10\%) was necessary, as otherwise only small metropolitan areas would have been sampled, while excluding all larger metropolitan areas. From each subset (i.e., top and bottom $20 \%$ ), we again randomly picked 16 counties. As a result, the counties within each of our two conditions (i.e., religious / non-religious) were stratified by urbanity, but otherwise random. Figure 1 in the main text shows that our sampling approach led to a fair geographical spread across the U.S. Moreover, the reported descriptive statistics in Table S3 show that our sampled counties indeed cover very diverse living environments (e.g., ranging from remote areas with less than one inhabitant per square mile to urban cores with more than 1,200 inhabitants per square mile).

Step 2 sampled people buried in the 64 counties selected in step 1 (32 religious counties and 32 non-religious counties). To do so, we relied on the world's largest collection of gravesite information, which holds more than 180 million entries of deceased people: findagrave.com (Find A Grave, 2019). For each of the 64 sampled counties, we identified the largest cemetery (most memorials) on findagrave.com. From each of these largest cemeteries, we randomly sampled 50 men and 50 women who passed away since January $1^{\text {st }} 2000$ and featured a gravestone photo (which was the case for $81 \%$ of all deceased people in the sampled cemeteries). Our sampling approach eventually resulted in a data set comprising 6,400 deceased people from 64 different counties. With 64 level two units (i.e., counties) each containing 100 observations (i.e., 50 men and 50 women) our sample is sufficiently large and well-powered for mixed-effects modeling (Maas \& Hox, 2005). 


\section{Coding Approach}

We used the gravestone photographs provided on findagrave.com to extract (a) deceased people's age at death and (b) their religiosity. To identify religious imagery elements on gravestones, we relied on Zelinsky's (2007) scheme that classifies frequently occurring elements of gravestone imagery as stemming from a secular or religious background. To code our data, we transferred Zelinsky's scheme into the coding manual provided in Table S1.

To assess the reliability of our coding approach, a second independent coder used the same manual (Table S1) to code a randomly drawn subset of 200 gravestones. This subset was unbeknownst to the coder - stratified in a way that it contained 100 graves with religious imagery and 100 graves without religious imagery. We then evaluated intercoder reliability (Cohen's Kappa for categorical variables, the intraclass correlation coefficient [ICC] for metric variables; Gwet, 2014). Table S2 shows that all types of gravestone elements featured nearperfect intercoder reliability.

\section{Gravestone Religiosity Measure}

We chose the five most frequently occurring religious imagery elements (i.e., cross, book, praying hands, passages of religious scripture, and angels; Table S3) and examined their ability to discriminate between religious and non-religious counties. As shown in Figure 3, symbols that discriminated very well between religious and non-religious counties were the book (102\% higher likelihood of occurrence in religious than non-religious counties), praying Hands (87\% higher likelihood in religious counties), and the angel (102\% higher likelihood). The presence of any Book-Praying-Angel imagery discriminated very well between religious and non-religious counties in urban settings $\left(M_{\text {religious }}=0.21 / M_{\text {non-religious }}=0.10 ; t(3,198)=-8.03, p\right.$ $<.001)$ and in rural settings $\left(M_{\text {religious }}=0.23 / M_{\text {non-religious }}=0.12 ; t(3,198)=-8.22, p<.001\right)$. By contrast, the cross (only 18\% higher likelihood of occurrence in religious than non-religious 
counties) and passages of scripture (13\% higher likelihood) discriminated rather poorly. The presence of Cross-Verbal imagery only discriminated between religious and non-religious counties in urban settings $\left(M_{\text {religious }}=0.32 / M_{\text {non-religious }}=0.41 ; t(3,198)=-5.13, p<.001\right)$, but not in rural settings $\left(M_{\text {religious }}=0.29 / M_{\text {non-religious }}=0.30 ; t(3,198)=-0.93, p=.35\right)$. In fact, the cross is the most common image in our data. It seems plausible that the cross has become a standard feature of gravestone design in the U.S. For example, military badges on veterans' gravestones almost by default carry crosses. In our data, $78 \%$ of the gravestones that contained a military marker, also featured a cross. Taken together, deceased people who were only loosely affiliated with their religion might often feature standard Christian symbols (such as the cross) on their gravestones. In contrast, more specific religious imagery (like bibles, praying hands, or angels) might only be picked by (or for) truly devout people.

In the previous paragraph, we sought to validate our gravestone religiosity measure by aggregating it to the county level and testing its association with county religiosity. However, findings from the aggregate level not necessarily need to generalize to the individual level-a problem known as ecological fallacy (Robinson, 1950). To cross-validate Book-Praying-Angel imagery as a marker of deceased people's religiosity, we sought to perform an additional individual-level validity test. Specifically, we made use of the fact that findagrave.com sometimes provides additional information about deceased people in form of short texts written by descendants. If our gravestone religiosity measure indeed reflects deceased people's religiosity, we would expect that for people with Book-Praying-Angel imagery on their gravestones, these texts contain more religious content.

If a text was given at all, in most cases it was a very short obituary simply stating information regarding the date, time and location of the funeral ceremony as well as the names of 
the closest descendants. In some cases, however, these texts were no simple obituaries, but rather short biographies - that is, texts that are longer and contain more information about the deceased person. To focus on these informative biographies, we only kept texts that were at least 300 words long $(N=448)$. Before analyzing these texts, we followed standard approaches in text analysis (Welbers, Van Atteveldt, \& Benoit, 2017) and removed any signs that were not letters, removed all filler words that have no substantial meaning (so-called stop words) and reduced inflected words to their word stem (so-called stemming). To identify words with religious meaning within these cleaned texts, we used the religiosity dimension of the well-established LIWC dictionary (Pennebaker, Boyd, Jordan, \& Blackburn, 2015). Given our focus on Christianity, from the list of 174 religious words within the 2015 LIWC dictionary, we erased 46 words that clearly stemmed from a non-Christian background (e.g., allah, buddha, imam, kosher, krishna, mosque, rabbi, sikh). We then counted how often the remaining 128 religious words occur within each of the 448 cleaned texts. Finally, we divided the number of religious words by the total number of words in the cleaned text. On average, $3.19 \%$ of all words within the cleaned texts were religious. Importantly, we found that in biographies of people with Book-PrayingAngel imagery on their gravestone religious words occurred much more frequently (48\% more often; $\left.M_{\mathrm{bpa}}=.044 / M_{\text {non-bpa }}=.029 ; t(446)=-4.56, p<.001\right)$ than for people without such imagery. By contrast, for the poorly discriminating imagery elements (i.e., the cross and verbal scriptures) this difference was much smaller and not significant ( $15 \%$ more often; $M_{\mathrm{cv}}=.035$ / $\left.M_{\text {non-cv }}=.030 ; t(446)=-1.82, p=.07\right)$.

Given the converging evidence from the aggregate and individual level, we used the Book-Praying-Angel imagery to measure deceased people's religiosity. To transfer Book- 
Praying-Angel imagery into a specific gravestone religiosity measure, we devised four different indicators of gravestone religiosity:

(1) dummy variable indicating whether any of the three imagery elements are present,

(2) sum variable indicating the number of the three imagery elements,

(3) share variable indicating the share of the three elements relative to the total number of imagery elements,

(4) ratio variable indicating the ratio between the sum of the three elements and the sum of non-religious imagery elements.

To select one of these four indicators, we tried to find the indicator that showed the highest external validity. To do so, we aggregated the individual scores for each indicator to the county-level and then correlated these aggregated scores with the share of religious adherents in the county $(N=64)$. We found the strongest correlation for the share indicator $(\beta=.56)$ followed by the dummy indicator $(\beta=.54)$, the sum indicator $(\beta=.51)$, and the ratio indicator $(\beta=.50)$. Therefore, we used the share indicator (i.e., the share of Book-Praying-Angel imagery on the total number of imagery elements) to measure gravestone religiosity in our main analyses. Nevertheless, we also tested the remaining three indicators and found similar results (see robustness checks later). 
Table S1

Coding Manual and Coding Examples from our Data

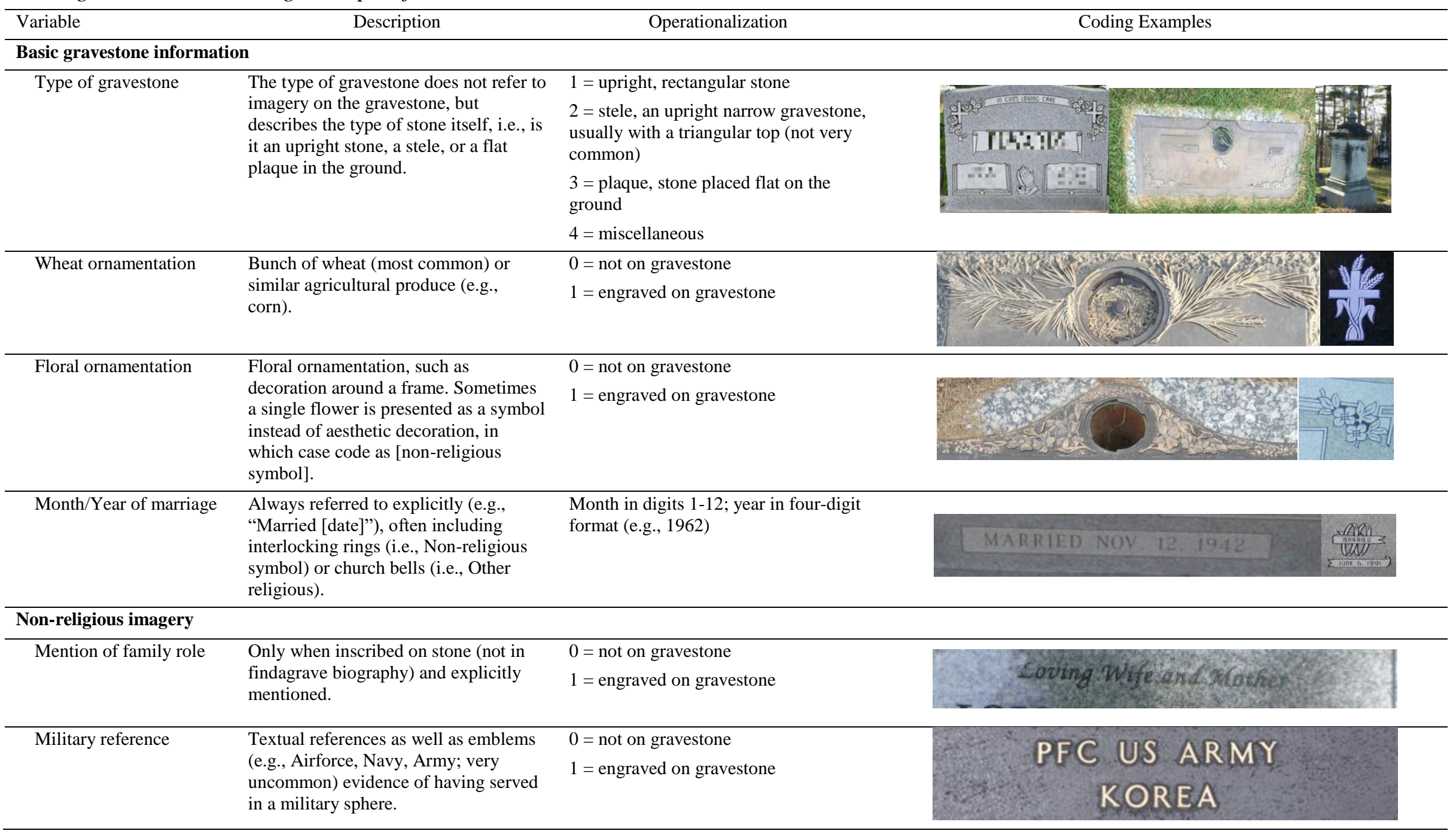




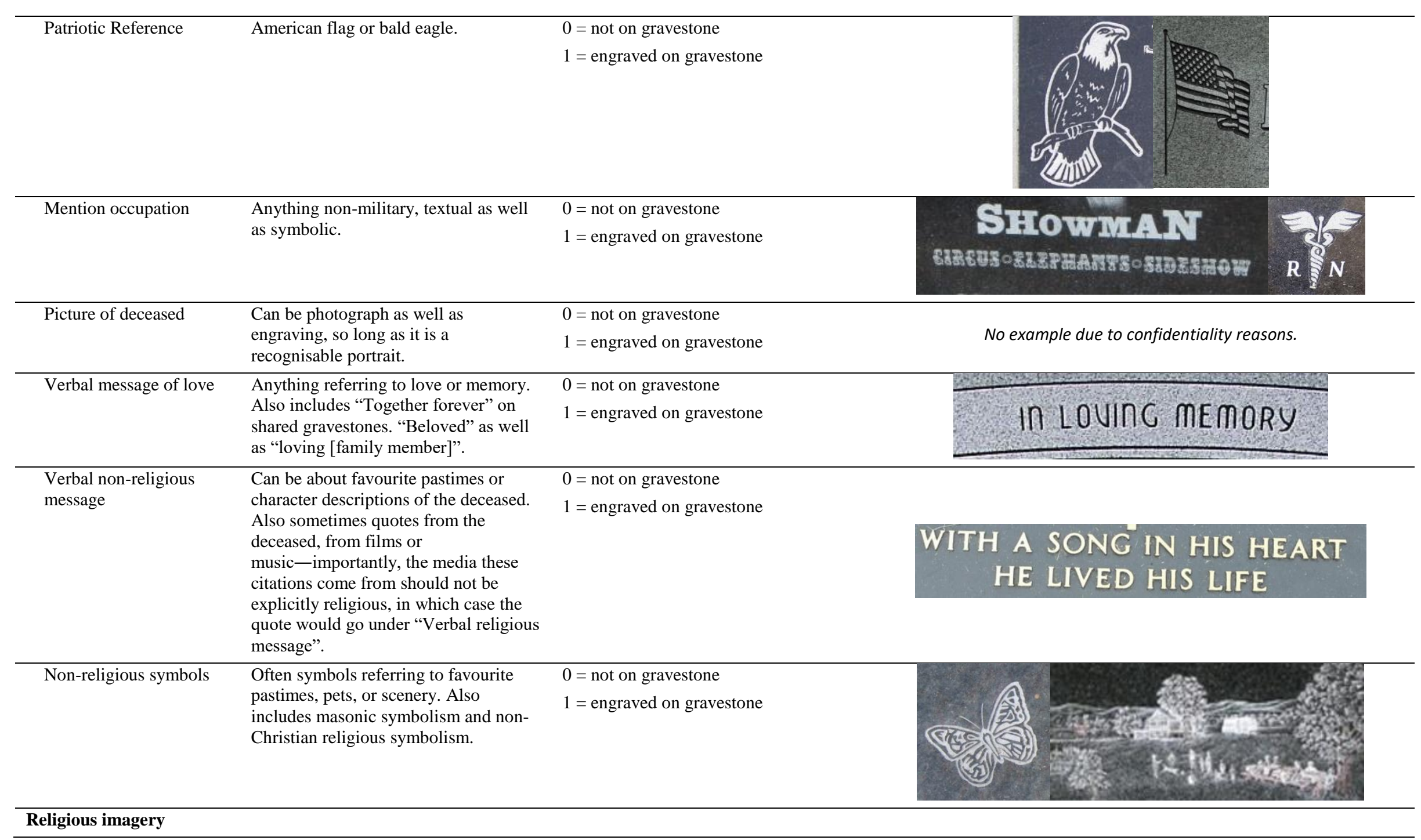




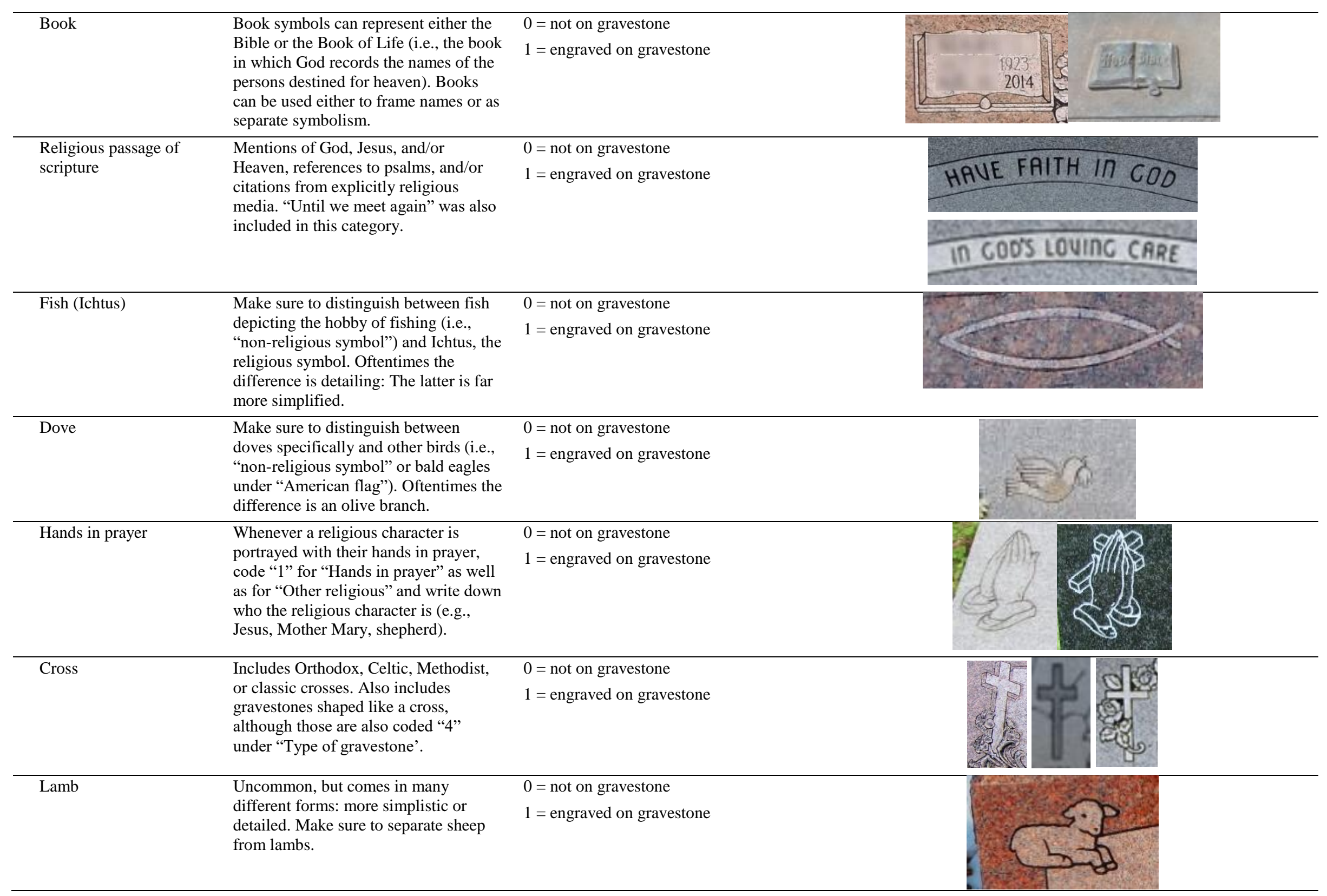




\begin{tabular}{lll}
\hline Angel & $\begin{array}{l}\text { Or cherubs. Winged, (often) robed } \\
\text { icons, often with halos. Note that } \\
\text { angels are frequently depicted with } \\
\text { their hands in prayer, which is coded } \\
\text { for separately as 1 under Hands in } \\
\text { prayer. }\end{array}$ & $1=$ engraved on gravestone \\
\hline Other religious & $\begin{array}{l}\text { Among others, Gothic windows, } \\
\text { Death's Head, fingers [pointing } \\
\text { toward/from Heaven], symbols of } \\
\text { divinity, statuaries, [Heaven's] gates, } \\
\text { hands reaching down, effigies, and } \\
\text { symbols of churches. }\end{array}$ & $0=$ not on gravestone \\
\end{tabular}


Table S2

Tests for Intercoder Reliability

\begin{tabular}{lcc}
\hline Variable & Measure & Intercoder Reliability \\
\hline Gravestone Religiosity & & $.89, p<.001$ \\
Any Religious Imagery (Dummy) & Cohen's Kappa & $.85, p<.001$ \\
Sum of All Religious Imagery (Sum) & ICC (1,1) & $.88, p<.001$ \\
Cross-Scripture (Dummy) & Cohen's Kappa & $.89, p<.001$ \\
Book-Praying-Angel (Dummy) & Cohen's Kappa & $.91, p<.001$ \\
Book -Praying-Angel (Sum) & ICC (1,1) & $.86, p<.001$ \\
Book -Praying-Angel (Share) & ICC $(1,1)$ & $.89, p<.001$ \\
Book -Praying-Angel (Ratio) & ICC $(1,1)$ & $.996, p<.001$ \\
Further Gravestone Information & & $.83, p<.001$ \\
Reached Age & ICC (1,1) & $.78, p<.001$ \\
Total Number Imagery (Sum) & ICC (1,1) & $.77, p<.001$ \\
No Imagery at All (Dummy) & Cohen's Kappa & $.89, p<.001$ \\
Sum of Non-Religious Imagery (Sum) & ICC (1,1) & $.96, p<.001$ \\
Type of Gravestone (Dummy) & Cohen's Kappa & $.90, p<.001$ \\
Number Persons in Grave (Sum) & ICC (1,1) & $.76, p<.001$ \\
Floral Ornamentation (Dummy) & Cohen's Kappa & Cohen's Kappa \\
Wheat Ornamentation (Dummy) & & \\
\hline
\end{tabular}




\section{Table S3}

Descriptive Statistics

\begin{tabular}{|c|c|c|c|c|c|}
\hline Variable & $N$ & $M$ & $S D$ & Min & Max \\
\hline \multicolumn{6}{|l|}{ Demographic Characteristics } \\
\hline Reached Age & 6,400 & 78.77 & 15.24 & .17 & 115.17 \\
\hline Female & 6,400 & .50 & .50 & 0 & 1 \\
\hline \multicolumn{6}{|l|}{ Religious Imagery } \\
\hline Any Religious Imagery & 6,400 & .44 & .50 & 0 & 1 \\
\hline Cross Symbol & 6,400 & .29 & .45 & 0 & 1 \\
\hline Book Symbol & 6,400 & .10 & .30 & 0 & 1 \\
\hline Praying Hands & 6,400 & .07 & .26 & 0 & 1 \\
\hline Verbal Scripture & 6,400 & .07 & .25 & 0 & 1 \\
\hline Angels & 6,400 & .02 & .13 & 0 & 1 \\
\hline Fish & 6,400 & .001 & .03 & 0 & 1 \\
\hline Dove & 6,400 & .01 & .11 & 0 & 1 \\
\hline Lamb & 6,400 & .002 & .04 & 0 & 1 \\
\hline Other Religious & 6,400 & .03 & .16 & 0 & 1 \\
\hline \multicolumn{6}{|l|}{ Other grave information } \\
\hline Type $=$ Upright Stone & 6,400 & .44 & .50 & 0 & 1 \\
\hline Number Persons in Grave & 6,400 & 1.66 & .73 & 1 & 11 \\
\hline Ornamentation Present & 6,400 & .43 & .50 & 0 & 1 \\
\hline Total Number Imagery & 6,400 & 1.46 & 1.21 & 0 & 8 \\
\hline No Imagery at All & 6,400 & .25 & .43 & 0 & 1 \\
\hline Any Non-Religious Imagery & 6,400 & .60 & .49 & 0 & 1 \\
\hline Marriage Information & 6,400 & .15 & .35 & 0 & 1 \\
\hline \multicolumn{6}{|l|}{ County Characteristics } \\
\hline Religious Condition & 64 & 0.50 & 0.50 & 0.00 & 1.00 \\
\hline Urban Condition & 64 & 0.50 & 0.50 & 0.00 & 1.00 \\
\hline Population Density & 64 & 56.86 & 172.35 & 0.25 & 1285.51 \\
\hline$\%$ Religious Adherents & 64 & 546.09 & 309.02 & 124.54 & 1099.39 \\
\hline$\%$ White & 64 & 86.49 & 12.36 & 52.77 & 98.08 \\
\hline$\%$ Uninsured & 64 & 11.48 & 4.58 & 4.80 & 26.10 \\
\hline \% With Diploma & 64 & 16.76 & 8.04 & 4.60 & 42.50 \\
\hline$\%$ In Poverty & 64 & 10.40 & 4.37 & 3.90 & 21.60 \\
\hline$\%$ Vacant Housing & 64 & 21.61 & 13.80 & 4.30 & 70.60 \\
\hline$\%$ Obese & 64 & 29.16 & 4.74 & 13.97 & 37.27 \\
\hline$\%$ Smoking & 64 & 17.57 & 3.60 & 10.53 & 25.40 \\
\hline$\%$ Excessive Drinkers & 64 & 17.20 & 2.75 & 10.67 & 22.90 \\
\hline
\end{tabular}




\section{Robustness Checks}

We conducted 14 robustness checks (Table S4) to scrutinize the robustness of our basic findings (M1). First, we accounted for a wide variety of further gravestone information (R1), including (a) total number of imagery elements, (b) absence of any imagery, (c) presence of nonreligious imagery, (d) marital status, (e) number of deceased people in grave, and (f) floral or wheat ornamentation. Additionally, we controlled for various county-level characteristics (R2), including (g) racial composition and population density (five-year estimates from the 2015 American Community Survey; United States Census Bureau, 2019), (h) estimates for the social determinants of health (i.e., 2015 five-year estimates in rates of health insurance, educational attainment, poverty prevalence, and vacant housing; Centers for Disease Control and Prevention, 2019), and (i) estimates for the most relevant behavioral health risk indicators (i.e., 2017 threeyear estimates in rates of obesity, excessive drinking, and tobacco use; County Health Rankings \& Roadmaps, 2019).

Second, some of our sampled counties were located in a certain proximity to each other. To rule out that our results are an artefact of a superordinate level, we included state-level fixed effects (R3).

Third, we tested whether gender (R4) and urbanity (R5) (i.e., our two stratification criteria) moderated the interaction between gravestone religiosity and county religiosity. To this end, we added three-way interaction terms consisting of Gravestone Religiosity $\times$ County Religiosity $\times$ Stratification criteria to our models.

Fourth, we altered our age-related inclusion criterion. Specifically, we lowered it (including all people down to minus one standard deviation below the mean age; R6), raised it (75-99 years; R7), and included all people who reached an age of 70+ (including people who reached an age of $100+; \mathrm{R} 8)$. 
Fifth, we tested alternative empirical specifications of gravestone religiosity. To this end, we measured gravestone religiosity not as the share of Book-Praying-Angel imagery, but also in the dummy (R9), sum (R10), and ratio (R11) operationalizations.

Sixth, for some deceased people, their burial county might not be the cultural context that was relevant throughout their lifetime. Therefore, we tried to rule out that our findings are driven by wrongfully assigning deceased people to cultural contexts that were not relevant to them. To do so, we rerun our analyses using only those 1,060 deceased people for whom additional information on findagrave.com allowed us to assure that their places of death and burial were identical (R12).

Seventh, deceased people who reached a higher age are also more likely (a) to belong to an earlier birth cohort and/or (b) to have died in a later period. To rule out that our findings are due to cohort and period effects, we controlled for the year of birth (R13) and the year of death $(\mathrm{R} 14) .^{2}$

Taken together, for all 14 robustness checks ${ }^{3}$, the main-text results remained conceptually unchanged. In other words, our results held against a wide variety of alternative explanations, different empirical specifications, and generalized across gender and living environments. Finally, given that we ran 15 models (our main-text model and the 14 robustness checks described in the previous section), we adjusted for the increased chance of Type I errors in

${ }^{2}$ Note that R12 and R13 are particularly conservative robustness tests. Specifically, reducing our sample to only 1,065 observations in R12 greatly decreased the statistical power of our analyses. Likewise, accounting for year of birth in R13 restricted the explainable variance in longevity to only 18 years (i.e., in what year between 2000 and 2018 a person died).

${ }^{3}$ Note that all multi-level models reached convergence. However, models R3, R4, R8, R12, and R13 were singular (i.e., variances of one or more linear combinations of effects were close to zero) and standard errors for the randomeffect parameters could not be calculated. Therefore, for each of these five models, we additionally tested a more parsimonious alternative model (Bates, Kliegl, Vasishth, \& Baayen, 2015) without random slopes. Those alternative models lead to identical results. 
multiple testing, using Simes Step-Up False-Discovery Rate (Yekutieli \& Benjamini, 2001).

Table S5 shows the $p$-values for the original Gravestone Religiosity $\times$ County Religiosity crosslevel interaction and also the new, adjusted $p$-values (typically called $q$-values). Corroborating the robustness of our findings, all $q$-values fell below the $95 \%$ significance threshold. 
Table S4.

Multi-Level Regression Results for Gravestone Religiosity and Longevity alongside 14 Robustness Checks.

\begin{tabular}{|c|c|c|c|c|c|c|c|c|c|c|c|c|c|c|c|}
\hline DV = Reached Age & $\begin{array}{c}\text { M1 } \\
\text { Base } \\
\text { Model }\end{array}$ & $\begin{array}{c}\text { R1 } \\
\text { Grave } \\
\text { Controls }\end{array}$ & $\begin{array}{c}\mathrm{R} 2 \\
\text { County } \\
\text { Controls }\end{array}$ & $\begin{array}{c}\text { R3 } \\
\text { State } \\
\text { Fixed } \\
\text { Effects } \\
\end{array}$ & $\begin{array}{c}\text { R4 } \\
\text { Gender } \\
\text { Moderat. }\end{array}$ & $\begin{array}{c}\text { R5 } \\
\text { Urbanity } \\
\text { Moderat. }\end{array}$ & $\begin{array}{c}\text { R6 } \\
\text { Age>> } \\
-1 S D\end{array}$ & $\begin{array}{c}\text { R7 } \\
\text { Age }>=75\end{array}$ & $\begin{array}{c}\text { R8 } \\
\text { Age all } \\
>=70\end{array}$ & $\begin{array}{c}\text { R9 } \\
\text { Gravest. } \\
\text { Religiosity } \\
\text { = Dummy }\end{array}$ & $\begin{array}{c}\text { R10 } \\
\text { Gravest. } \\
\text { Religiosity } \\
=\text { Sum }\end{array}$ & $\begin{array}{c}\text { R11 } \\
\text { Gravest. } \\
\text { Religiosity } \\
=\text { Ratio }\end{array}$ & $\begin{array}{c}\text { R12 } \\
\text { Burial }= \\
\text { Death } \\
\text { Place }\end{array}$ & $\begin{array}{c}\text { R13 } \\
\text { Cohort } \\
\text { Effects }\end{array}$ & $\begin{array}{c}\text { R14 } \\
\text { Period } \\
\text { Effects }\end{array}$ \\
\hline \multicolumn{16}{|l|}{ Base Variables } \\
\hline Gravestone Religiosity & $\begin{array}{l}-0.00 \\
(0.11)\end{array}$ & $\begin{array}{c}0.01 \\
(0.13)\end{array}$ & $\begin{array}{c}0.02 \\
(0.13)\end{array}$ & $\begin{array}{c}0.03 \\
(0.13)\end{array}$ & $\begin{array}{c}0.23 \\
(0.19)\end{array}$ & $\begin{array}{l}0.08 \\
(0.16)\end{array}$ & $\begin{array}{l}-0.04 \\
(0.15)\end{array}$ & $\begin{array}{l}-0.02 \\
(0.12)\end{array}$ & $\begin{array}{c}0.12 \\
(0.13)\end{array}$ & $\begin{array}{c}0.07 \\
(0.37)\end{array}$ & $\begin{array}{c}0.02 \\
(0.14)\end{array}$ & $\begin{array}{c}0.05 \\
(0.13)\end{array}$ & $\begin{array}{l}-0.03 \\
(0.28)\end{array}$ & $\begin{array}{l}-0.13 \\
(0.07)\end{array}$ & $\begin{array}{c}0.05 \\
(0.13)\end{array}$ \\
\hline County Religiosity & $\begin{array}{c}0.10 \\
(0.15)\end{array}$ & $\begin{array}{l}0.18 \\
(0.15)\end{array}$ & $\begin{array}{c}0.11 \\
(0.19)\end{array}$ & $\begin{array}{l}1.11^{* *} \\
(0.39)\end{array}$ & $\begin{array}{l}0.10 \\
(0.22)\end{array}$ & $\begin{array}{c}0.32 \\
(0.21)\end{array}$ & $\begin{array}{c}0.02 \\
(0.21)\end{array}$ & $\begin{array}{c}0.20 \\
(0.15)\end{array}$ & $\begin{array}{c}0.10 \\
(0.20)\end{array}$ & $\begin{array}{l}-0.01 \\
(0.19)\end{array}$ & $\begin{array}{c}0.10 \\
(0.18)\end{array}$ & $\begin{array}{c}0.10 \\
(0.19)\end{array}$ & $\begin{array}{c}0.54 \\
(0.33)\end{array}$ & $\begin{array}{c}0.12 \\
(0.11)\end{array}$ & $\begin{array}{c}0.09 \\
(0.19)\end{array}$ \\
\hline $\begin{array}{l}\text { Gravestone X } \\
\text { County Religiosity }\end{array}$ & $\begin{array}{l}0.30^{* *} \\
(0.10)\end{array}$ & $\begin{array}{l}0.31^{* *} \\
(0.10)\end{array}$ & $\begin{array}{l}0.32^{* *} \\
(0.10)\end{array}$ & $\begin{array}{l}0.30^{* *} \\
(0.10)\end{array}$ & $\begin{array}{l}0.42^{* *} \\
(0.16)\end{array}$ & $\begin{array}{l}0.35^{* * *} \\
(0.12)\end{array}$ & $\begin{array}{l}0.28^{*} \\
(0.12)\end{array}$ & $\begin{array}{l}0.24^{* *} \\
(0.09)\end{array}$ & $\begin{array}{l}0.29^{* *} \\
(0.11)\end{array}$ & $\begin{array}{l}0.69^{*} \\
(0.31)\end{array}$ & $\begin{array}{l}0.28^{*} \\
(0.11)\end{array}$ & $\begin{array}{l}0.29^{* *} \\
(0.11)\end{array}$ & $\begin{array}{l}0.70^{* *} \\
(0.23)\end{array}$ & $\begin{array}{l}0.13^{*} \\
(0.06)\end{array}$ & $\begin{array}{l}0.30^{* *} \\
(0.10)\end{array}$ \\
\hline Female & $\begin{array}{l}2.44^{* * * *} \\
(0.20)\end{array}$ & $\begin{array}{l}2.06^{* * *} \\
(0.21)\end{array}$ & $\begin{array}{l}2.05^{5 * *} \\
(0.21)\end{array}$ & $\begin{array}{l}2.06^{4 * 8} \\
(0.21)\end{array}$ & $\begin{array}{l}2.08^{* * *} \\
(0.21)\end{array}$ & $\begin{array}{l}2.05^{-5 *} \\
(0.21)\end{array}$ & $\begin{array}{l}2.51^{* * * *} \\
(0.23)\end{array}$ & $\begin{array}{l}1.76^{* * z} \\
(0.19)\end{array}$ & $\begin{array}{l}2.34^{* * * *} \\
(0.21)\end{array}$ & $\begin{array}{l}2.06^{* * * *} \\
(0.21)\end{array}$ & $\begin{array}{l}2.06^{* * * *} \\
(0.21)\end{array}$ & $\begin{array}{l}2.06^{* * *} \\
(0.21)\end{array}$ & $\begin{array}{l}2.97^{* * *} \\
(0.44)\end{array}$ & $\begin{array}{l}0.86^{* * *} \\
(0.12)\end{array}$ & $\begin{array}{l}1.99^{*+*} \\
(0.20)\end{array}$ \\
\hline Urban & $\begin{array}{c}0.11 \\
(0.30)\end{array}$ & $\begin{array}{c}0.09 \\
(0.29)\end{array}$ & $\begin{array}{c}0.03 \\
(0.36)\end{array}$ & $\begin{array}{c}0.33 \\
(0.35)\end{array}$ & $\begin{array}{c}0.03 \\
(0.36)\end{array}$ & $\begin{array}{l}0.14 \\
(0.35)\end{array}$ & $\begin{array}{l}-0.27 \\
(0.41)\end{array}$ & $\begin{array}{c}0.18 \\
(0.29)\end{array}$ & $\begin{array}{l}-0.12 \\
(0.38)\end{array}$ & $\begin{array}{c}0.07 \\
(0.36)\end{array}$ & $\begin{array}{c}0.08 \\
(0.35)\end{array}$ & $\begin{array}{c}0.08 \\
(0.36)\end{array}$ & $\begin{array}{c}0.10 \\
(0.59)\end{array}$ & $\begin{array}{c}0.26 \\
(0.21)\end{array}$ & $\begin{array}{l}-0.03 \\
(0.37)\end{array}$ \\
\hline $\begin{array}{l}\text { Grave Controls } \\
\text { Sum of All Imagery }\end{array}$ & & $\begin{array}{l}-0.52^{* * *} \\
(0.16)\end{array}$ & $\begin{array}{l}-0.51^{* *} \\
(0.16)\end{array}$ & $\begin{array}{l}-0.48^{* *} \\
(0.16)\end{array}$ & $\begin{array}{l}-0.51^{* *} \\
(0.16)\end{array}$ & $\begin{array}{l}-0.50^{* *} \\
(0.16)\end{array}$ & $\begin{array}{l}-0.59^{* * *} \\
(0.17)\end{array}$ & $\begin{array}{l}-0.44^{* *} \\
(0.14)\end{array}$ & $\begin{array}{c}-0.64^{* * *} \\
(0.16)\end{array}$ & $\begin{array}{l}-0.54^{* *} \\
(0.17)\end{array}$ & $\begin{array}{l}-0.53^{* *} \\
(0.17)\end{array}$ & $\begin{array}{l}-0.53^{* *} \\
(0.16)\end{array}$ & $\begin{array}{l}-0.20 \\
(0.33)\end{array}$ & $\begin{array}{c}0.17 \\
(0.09)\end{array}$ & $\begin{array}{c}-0.58^{* *+} \\
(0.16)\end{array}$ \\
\hline No Imagery & & $\begin{array}{c}0.14 \\
(0.40)\end{array}$ & $\begin{array}{c}0.17 \\
(0.40)\end{array}$ & $\begin{array}{c}0.22 \\
(0.40)\end{array}$ & $\begin{array}{c}0.15 \\
(0.40)\end{array}$ & $\begin{array}{c}0.17 \\
(0.40)\end{array}$ & $\begin{array}{c}0.47 \\
(0.44)\end{array}$ & $\begin{array}{c}0.17 \\
(0.36)\end{array}$ & $\begin{array}{c}0.39 \\
(0.41)\end{array}$ & $\begin{array}{c}0.10 \\
(0.37)\end{array}$ & $\begin{array}{c}0.09 \\
(0.37)\end{array}$ & $\begin{array}{c}0.13 \\
(0.38)\end{array}$ & $\begin{array}{l}1.42 \\
(0.83)\end{array}$ & $\begin{array}{c}0.04 \\
(0.23)\end{array}$ & $\begin{array}{c}0.18 \\
(0.39)\end{array}$ \\
\hline Non-Relig. Imagery & & $\begin{array}{l}-0.51 \\
(0.35)\end{array}$ & $\begin{array}{l}-0.50 \\
(0.35)\end{array}$ & $\begin{array}{l}-0.49 \\
(0.35)\end{array}$ & $\begin{array}{l}-0.50 \\
(0.35)\end{array}$ & $\begin{array}{l}-0.49 \\
(0.35)\end{array}$ & $\begin{array}{l}-0.54 \\
(0.39)\end{array}$ & $\begin{array}{l}-0.42 \\
(0.32)\end{array}$ & $\begin{array}{l}-0.28 \\
(0.36)\end{array}$ & $\begin{array}{l}-0.55 \\
(0.33)\end{array}$ & $\begin{array}{l}-0.55 \\
(0.34)\end{array}$ & $\begin{array}{l}-0.53 \\
(0.33)\end{array}$ & $\begin{array}{c}0.21 \\
(0.73)\end{array}$ & $\begin{array}{c}0.08 \\
(0.20)\end{array}$ & $\begin{array}{l}-0.56 \\
(0.35)\end{array}$ \\
\hline Marriage Mentioned & & $\begin{array}{l}-0.86^{* *} \\
(0.31)\end{array}$ & $\begin{array}{l}-0.85^{* *} \\
(0.32)\end{array}$ & $\begin{array}{l}-0.94^{* *} \\
(0.32)\end{array}$ & $\begin{array}{l}-0.85^{* *} \\
(0.32)\end{array}$ & $\begin{array}{l}-0.88^{* *} \\
(0.32)\end{array}$ & $\begin{array}{l}-0.77^{*} \\
(0.35)\end{array}$ & $\begin{array}{l}-0.83^{* *} \\
(0.29)\end{array}$ & $\begin{array}{l}-0.97^{* *} \\
(0.33)\end{array}$ & $\begin{array}{l}-0.86^{* *} \\
(0.32)\end{array}$ & $\begin{array}{l}-0.86^{* *} \\
(0.32)\end{array}$ & $\begin{array}{l}-0.85^{* *} \\
(0.32)\end{array}$ & $\begin{array}{l}-0.06 \\
(0.65)\end{array}$ & $\begin{array}{c}0.30 \\
(0.18)\end{array}$ & $\begin{array}{l}-0.98^{* *} \\
(0.32)\end{array}$ \\
\hline Persons in Grave & & $\begin{array}{l}0.51^{* * *} \\
(0.11)\end{array}$ & $\begin{array}{l}0.50^{* * *} \\
(0.11)\end{array}$ & $\begin{array}{l}0.49^{* * s} \\
(0.11)\end{array}$ & $\begin{array}{l}0.49^{* * *} \\
(0.11)\end{array}$ & $\begin{array}{l}0.51^{* * * *} \\
(0.11)\end{array}$ & $\begin{array}{l}0.82^{* * *} \\
(0.12)\end{array}$ & $\begin{array}{l}0.30^{* *} \\
(0.10)\end{array}$ & $\begin{array}{l}0.50^{* * *} \\
(0.12)\end{array}$ & $\begin{array}{l}0.49^{* * *} \\
(0.11)\end{array}$ & $\begin{array}{l}0.49^{* * *} \\
(0.11)\end{array}$ & $\begin{array}{l}0.49^{* * *} \\
(0.11)\end{array}$ & $\begin{array}{c}0.18 \\
(0.24)\end{array}$ & $\begin{array}{l}0.13^{*} \\
(0.06)\end{array}$ & $\begin{array}{l}0.50^{s+*} \\
(0.11)\end{array}$ \\
\hline Type of Gravestone & & $\begin{array}{l}-0.17 \\
(0.24)\end{array}$ & $\begin{array}{l}-0.16 \\
(0.25)\end{array}$ & $\begin{array}{l}0.07 \\
(0.25)\end{array}$ & $\begin{array}{l}-0.15 \\
(0.25)\end{array}$ & $\begin{array}{l}-0.22 \\
(0.25)\end{array}$ & $\begin{array}{l}-0.24 \\
(0.28)\end{array}$ & $\begin{array}{l}-0.03 \\
(0.22)\end{array}$ & $\begin{array}{l}-0.10 \\
(0.26)\end{array}$ & $\begin{array}{l}-0.12 \\
(0.25)\end{array}$ & $\begin{array}{l}-0.12 \\
(0.25)\end{array}$ & $\begin{array}{l}-0.13 \\
(0.25)\end{array}$ & $\begin{array}{c}0.09 \\
(0.53)\end{array}$ & $\begin{array}{l}0.17 \\
(0.14)\end{array}$ & $\begin{array}{l}-0.20 \\
(0.25)\end{array}$ \\
\hline Ornamentation & & $\begin{array}{l}0.70^{* *} \\
(0.22)\end{array}$ & $\begin{array}{l}0.72^{* *} \\
(0.22)\end{array}$ & $\begin{array}{l}0.76^{4 * 8} \\
(0.22)\end{array}$ & $\begin{array}{l}0.70^{* *} \\
(0.22)\end{array}$ & $\begin{array}{l}0.75^{2 * * *} \\
(0.22)\end{array}$ & $\begin{array}{l}0.76^{* *} \\
(0.25)\end{array}$ & $\begin{array}{l}0.47^{*} \\
(0.20)\end{array}$ & $\begin{array}{l}0.86^{* * *} \\
(0.23)\end{array}$ & $\begin{array}{l}0.72^{* s} \\
(0.22)\end{array}$ & $\begin{array}{l}0.72^{* *} \\
(0.22)\end{array}$ & $\begin{array}{l}0.72^{* * *} \\
(0.22)\end{array}$ & $\begin{array}{c}0.79 \\
(0.47)\end{array}$ & $\begin{array}{l}-0.07 \\
(0.13)\end{array}$ & $\begin{array}{l}0.79^{s+*} \\
(0.22)\end{array}$ \\
\hline $\begin{array}{l}\text { County Controls } \\
\text { Share Whites }\end{array}$ & & & $\begin{array}{c}-0.11 \\
(0.21)\end{array}$ & $\begin{array}{l}-0.09 \\
(0.26)\end{array}$ & $\begin{array}{l}-0.11 \\
(0.21)\end{array}$ & $\begin{array}{c}-0.08 \\
(0.20)\end{array}$ & $\begin{array}{l}-0.12 \\
(0.24)\end{array}$ & $\begin{array}{c}-0.06 \\
(0.17)\end{array}$ & $\begin{array}{l}-0.12 \\
(0.22)\end{array}$ & $\begin{array}{l}-0.14 \\
(0.21)\end{array}$ & $\begin{array}{c}-0.16 \\
(0.20)\end{array}$ & $\begin{array}{c}-0.14 \\
(0.21)\end{array}$ & $\begin{array}{c}0.13 \\
(0.35)\end{array}$ & $\begin{array}{l}-0.03 \\
(0.12)\end{array}$ & $\begin{array}{l}-0.11 \\
(0.22)\end{array}$ \\
\hline Population Density & & & $\begin{array}{c}-0.28 \\
(0.17)\end{array}$ & $\begin{array}{c}0.25 \\
(0.23)\end{array}$ & $\begin{array}{c}-0.28 \\
(0.17)\end{array}$ & $\begin{array}{c}-0.27 \\
(0.17)\end{array}$ & $\begin{array}{l}-0.41^{*} \\
(0.19)\end{array}$ & $\begin{array}{l}-0.21 \\
(0.13)\end{array}$ & $\begin{array}{c}-0.33 \\
(0.18)\end{array}$ & $\begin{array}{c}-0.28 \\
(0.17)\end{array}$ & $\begin{array}{c}-0.28 \\
(0.16)\end{array}$ & $\begin{array}{c}-0.27 \\
(0.16)\end{array}$ & $\begin{array}{l}-0.41 \\
(0.39)\end{array}$ & $\begin{array}{c}0.11 \\
(0.10)\end{array}$ & $\begin{array}{l}-0.33 \\
(0.18)\end{array}$ \\
\hline Uninsured & & & $\begin{array}{l}-0.19 \\
(0.22)\end{array}$ & $\begin{array}{l}-0.53 \\
(0.39)\end{array}$ & $\begin{array}{l}-0.20 \\
(0.22)\end{array}$ & $\begin{array}{l}-0.24 \\
(0.21)\end{array}$ & $\begin{array}{l}-0.19 \\
(0.24)\end{array}$ & $\begin{array}{l}-0.20 \\
(0.17)\end{array}$ & $\begin{array}{l}-0.15 \\
(0.23)\end{array}$ & $\begin{array}{l}-0.23 \\
(0.22)\end{array}$ & $\begin{array}{c}-0.28 \\
(0.21)\end{array}$ & $\begin{array}{c}-0.27 \\
(0.21)\end{array}$ & $\begin{array}{l}-0.15 \\
(0.37)\end{array}$ & $\begin{array}{l}-0.06 \\
(0.12)\end{array}$ & $\begin{array}{l}-0.20 \\
(0.22)\end{array}$ \\
\hline
\end{tabular}




\begin{tabular}{|c|c|c|c|c|c|c|c|c|c|c|c|c|c|}
\hline Diploma & $\begin{array}{c}0.04 \\
(0.17)\end{array}$ & $\begin{array}{c}0.01 \\
(0.17)\end{array}$ & $\begin{array}{c}0.04 \\
(0.17)\end{array}$ & $\begin{array}{c}0.01 \\
(0.16)\end{array}$ & $\begin{array}{c}-0.01 \\
(0.19)\end{array}$ & $\begin{array}{c}0.06 \\
(0.13)\end{array}$ & $\begin{array}{c}0.07 \\
(0.18)\end{array}$ & $\begin{array}{c}0.04 \\
(0.17)\end{array}$ & $\begin{array}{c}0.04 \\
(0.16)\end{array}$ & $\begin{array}{c}0.04 \\
(0.16)\end{array}$ & $\begin{array}{c}-0.13 \\
(0.32)\end{array}$ & $\begin{array}{c}0.04 \\
(0.10)\end{array}$ & $\begin{array}{c}0.04 \\
(0.17)\end{array}$ \\
\hline Poverty & $\begin{array}{l}-0.12 \\
(0.27)\end{array}$ & $\begin{array}{c}-0.34 \\
(0.28)\end{array}$ & $\begin{array}{c}-0.13 \\
(0.27)\end{array}$ & $\begin{array}{c}-0.07 \\
(0.26)\end{array}$ & $\begin{array}{c}-0.33 \\
(0.31)\end{array}$ & $\begin{array}{c}0.01 \\
(0.22)\end{array}$ & $\begin{array}{l}-0.20 \\
(0.29)\end{array}$ & $\begin{array}{l}-0.14 \\
(0.27)\end{array}$ & $\begin{array}{c}-0.14 \\
(0.27)\end{array}$ & $\begin{array}{c}-0.14 \\
(0.27)\end{array}$ & $\begin{array}{c}0.22 \\
(0.49)\end{array}$ & $\begin{array}{c}-0.07 \\
(0.16)\end{array}$ & $\begin{array}{l}-0.12 \\
(0.28)\end{array}$ \\
\hline Vacant Housing & $\begin{array}{l}-0.01 \\
(0.19)\end{array}$ & $\begin{array}{c}-0.02 \\
(0.20)\end{array}$ & $\begin{array}{c}-0.02 \\
(0.19)\end{array}$ & $\begin{array}{c}0.05 \\
(0.19)\end{array}$ & $\begin{array}{c}-0.18 \\
(0.21)\end{array}$ & $\begin{array}{c}-0.04 \\
(0.15)\end{array}$ & $\begin{array}{c}-0.08 \\
(0.20)\end{array}$ & $\begin{array}{c}-0.01 \\
(0.19)\end{array}$ & $\begin{array}{c}-0.02 \\
(0.19)\end{array}$ & $\begin{array}{c}-0.02 \\
(0.19)\end{array}$ & $\begin{array}{c}0.10 \\
(0.32)\end{array}$ & $\begin{array}{c}0.04 \\
(0.11)\end{array}$ & $\begin{array}{l}-0.02 \\
(0.20)\end{array}$ \\
\hline Obesity & $\begin{array}{c}0.05 \\
(0.25)\end{array}$ & $\begin{array}{l}-0.13 \\
(0.32)\end{array}$ & $\begin{array}{c}0.06 \\
(0.25)\end{array}$ & $\begin{array}{c}0.11 \\
(0.24)\end{array}$ & $\begin{array}{c}-0.07 \\
(0.28)\end{array}$ & $\begin{array}{c}0.08 \\
(0.20)\end{array}$ & $\begin{array}{l}-0.04 \\
(0.26)\end{array}$ & $\begin{array}{c}0.06 \\
(0.25)\end{array}$ & $\begin{array}{c}0.08 \\
(0.24)\end{array}$ & $\begin{array}{c}0.08 \\
(0.24)\end{array}$ & $\begin{array}{c}0.37 \\
(0.44)\end{array}$ & $\begin{array}{c}0.02 \\
(0.14)\end{array}$ & $\begin{array}{c}0.03 \\
(0.26)\end{array}$ \\
\hline Smoking & $\begin{array}{c}-0.29 \\
(0.25)\end{array}$ & $\begin{array}{c}0.45 \\
(0.29)\end{array}$ & $\begin{array}{c}-0.29 \\
(0.25)\end{array}$ & $\begin{array}{c}-0.23 \\
(0.25)\end{array}$ & $\begin{array}{c}-0.20 \\
(0.29)\end{array}$ & $\begin{array}{c}-0.25 \\
(0.21)\end{array}$ & $\begin{array}{l}-0.22 \\
(0.27)\end{array}$ & $\begin{array}{l}-0.27 \\
(0.26)\end{array}$ & $\begin{array}{c}-0.25 \\
(0.25)\end{array}$ & $\begin{array}{c}-0.27 \\
(0.25)\end{array}$ & $\begin{array}{c}-0.75 \\
(0.52)\end{array}$ & $\begin{array}{l}-0.07 \\
(0.15)\end{array}$ & $\begin{array}{l}-0.29 \\
(0.26)\end{array}$ \\
\hline Excessive Drinking & $\begin{array}{c}-0.06 \\
(0.20)\end{array}$ & $\begin{array}{c}-0.02 \\
(0.29)\end{array}$ & $\begin{array}{c}-0.07 \\
(0.20)\end{array}$ & $\begin{array}{c}-0.06 \\
(0.19)\end{array}$ & $\begin{array}{l}-0.20 \\
(0.23)\end{array}$ & $\begin{array}{c}-0.00 \\
(0.16)\end{array}$ & $\begin{array}{c}0.06 \\
(0.21)\end{array}$ & $\begin{array}{c}-0.10 \\
(0.20)\end{array}$ & $\begin{array}{c}-0.08 \\
(0.20)\end{array}$ & $\begin{array}{c}-0.10 \\
(0.20)\end{array}$ & $\begin{array}{c}0.07 \\
(0.35)\end{array}$ & $\begin{array}{l}-0.27^{*} \\
(0.12)\end{array}$ & $\begin{array}{l}-0.02 \\
(0.21)\end{array}$ \\
\hline
\end{tabular}

State Fixed Effects

YES

Three-Way Interactions

Gravestone X County

Female

-0.17
$(0.21)$

Gravestone X County

$-0.23$

\section{Cohort, Period Effects}

Year of Birth

Year of Death

\begin{tabular}{|c|c|c|c|c|c|c|c|c|c|c|c|c|c|c|c|}
\hline Constant & $\begin{array}{c}83.24^{* * * *} \\
(0.24)\end{array}$ & $\begin{array}{c}83.61^{* * * *} \\
(0.39)\end{array}$ & $\begin{array}{c}83.61^{* * *} \\
(0.39)\end{array}$ & $\begin{array}{c}84.84^{* * * *} \\
(1.04)\end{array}$ & $\begin{array}{c}83.61^{* * 5} \\
(0.39)\end{array}$ & $\begin{array}{c}83.53^{* * * *} \\
(0.39)\end{array}$ & $\begin{array}{c}82.18^{* * * *} \\
(0.44)\end{array}$ & $\begin{array}{c}85.11^{* * *} \\
(0.34)\end{array}$ & $\begin{array}{c}83.66^{* * 5} \\
(0.41)\end{array}$ & $\begin{array}{c}83.61^{* * * *} \\
(0.40)\end{array}$ & $\begin{array}{c}83.62^{* * * *} \\
(0.38)\end{array}$ & $\begin{array}{c}83.60^{*=8} \\
(0.38)\end{array}$ & $\begin{array}{c}82.32^{* * * *} \\
(0.82)\end{array}$ & $\begin{array}{c}1482.24^{* * * *} \\
(13.78)\end{array}$ & $\begin{array}{c}-257.62^{*+*} \\
(43.86)\end{array}$ \\
\hline Intercept Variance & 0.80 & 0.68 & 0.50 & 0.00 & 0.50 & 0.42 & 0.66 & 0.03 & 0.61 & 0.67 & 0.48 & 0.48 & 0.09 & 0.17 & 0.60 \\
\hline Slope Variance & 0.00 & 0.00 & 0.01 & 0.00 & 0.00 & 0.00 & 0.08 & 0.00 & 0.01 & 0.46 & 0.04 & 0.03 & 0.04 & 0.00 & 0.01 \\
\hline Within Between Variance & 50.29 & 49.30 & 49.30 & 49.09 & 49.23 & 49.29 & 65.80 & 36.45 & 54.16 & 49.25 & 49.30 & 49.29 & 47.00 & 15.99 & 48.65 \\
\hline Observations & 4,946 & 4,946 & 4,946 & 4,946 & 4,946 & 4,946 & 5,339 & 4,440 & 5,071 & 4,946 & 4,946 & 4,946 & 1,065 & 4,946 & 4,946 \\
\hline
\end{tabular}


Table S5

FDR-Corrected q-Values to Account for Multiple

Testing

\begin{tabular}{lcc}
\hline Model & $p$-value & $\begin{array}{c}\text { FDR-corrected } \\
q \text {-value }\end{array}$ \\
\hline M1 & .004 & .008 \\
R1 & .002 & .008 \\
R2 & .002 & .008 \\
R3 & .003 & .008 \\
R4 & .009 & .012 \\
R5 & .003 & .008 \\
R6 & .022 & .025 \\
R7 & .009 & .012 \\
R8 & .006 & .011 \\
R9 & .024 & .026 \\
R10 & .013 & .016 \\
R11 & .007 & .011 \\
R12 & .002 & .008 \\
R13 & .031 & .031 \\
R14 & .003 & .008 \\
\hline
\end{tabular}




\section{Other Supplementary Materials}

Gravestone data set (gravestone_data.csv).

Gravestone analysis script (gravestone_script.do) 